\title{
Economic feasibility study of a quarry mine under contractual risk in probabilistic approach
}

\author{
Jorge Luiz Valença Mariz ${ }^{1 *}$ \\ Suelen Silva Rocha ${ }^{1}$ (D) \\ Júlio César de Souza ${ }^{2}$
}

\begin{abstract}
An economic feasibility study must consider parameters and uncertainties inherent to a mining project, in which the risks must be properly quantified. An economic viability study by Discounted Cash Flow (DCF) elaborated for the implementation of Mega Mineração, in Pernambuco, Brazil, indicates a positive Net Present Value (NPV) of the deterministic scenario whose Internal Rate of Return (IRR) was higher than Minimum Acceptable Rate of Return (MARR), which indicates the project to be highly profitable. The probabilistic analysis, however, considered several risks in its assumptions and displayed that there was a $99.77 \%$ probability for the NPV to be positive and $49.98 \%$ to be greater than the deterministic NPV. Although more robust and reliable, the possibility of breaking the contract by either party was not considered in this analysis, which would make it impossible to obtain the results predicted for some scenarios. This study aims to assess the consequences of a breach of contract in each of the 15 years foreseen for the project through a probabilistic approach regarding risk and sensitivity analysis. The results indicate catastrophic consequences for the enterprise if the breach occurs in the first year of the project and suggest that the probability of achieving higher rates is attached to longer scenarios, by postponing or avoiding the breach of contract.
\end{abstract}

Keywords: Quarry mining; Mineral economics; Economic feasibility; Risk analysis.

\section{Estudo de viabilidade econômica e uma mina de agregados sob risco contratual em uma abordagem probabilística}

\section{Resumo}

Um estudo de viabilidade econômica deve considerar parâmetros e incertezas inerentes a um projeto mineiro, onde os riscos devem ser devidamente quantificados. Um estudo de viabilidade econômica por Fluxo de Caixa Descontado (FCD) elaborado para a implementação da Mega Mineração, Pernambuco, Brasil, indica um Valor Presente Líquido (VPL) positivo no cenário determinístico, cuja Taxa Interna de Retorno (TIR) foi superior à Taxa Mínima de Atratividade (TMA), apontando para um projeto altamente rentável. A análise probabilística, no entanto, considerou vários riscos em suas premissas e mostrou que havia $99,77 \%$ de probabilidade de o VPL ser positivo e 49,98\% de ser maior que o VPL determinístico. Embora mais robusta e confiável, a possibilidade de quebra do contrato por qualquer das partes não foi considerada nesta análise, o que impossibilitaria a obtenção dos resultados previstos para alguns cenários. Este estudo tem como objetivo avaliar as consequências da quebra do contrato em cada um dos 15 anos previstos para o projeto por meio de uma abordagem probabilística através de análises de risco e sensibilidade. Os resultados indicam consequências catastróficas para a empresa se a ruptura ocorrer no primeiro ano do projeto e sugerem que a probabilidade de obtenção de índices mais altos está associada a cenários mais longos, adiando ou evitando a quebra de contrato.

Palavras-chave: Mineração de agregados; Economia mineral; Viabilidade econômica; Análise de risco.

${ }^{\prime}$ Programa de Pós-Graduação em Engenharia de Minas, Metalúrgica e de Materiais, Universidade Federal do Rio Grande do Sul, Porto Alegre, RS, Brasil.

${ }^{2}$ Departamento de Engenharia de Minas, Universidade Federal de Pernambuco, Recife, PE, Brasil.

*Corresponding author: jorge valenca@hotmail.com

2176-1523 (C) 2021. Mariz et al. Published by ABM. This is an Open Access article distributed under the terms of the Creative Commons Attribution License, which permits unrestricted use, distribution, and reproduction in any medium, provided the original work is properly cited. 


\section{Introduction}

The study of a mining project generally involves three stages, which are: the conceptual, pre-feasibility and feasibility studies. However, in order to progress towards the last two phases, it is necessary to set a production schedule and its duration, among other variables, even though most information about the project might still be conjectural. Small variations in the boundary conditions of a project can have a significant impact on the design of the mine, its scheduling, its cash flow and the outcome of the project, to be in the order of millions of dollars. Due to the large number of parameters considered, mine planning is associated with numerous sources of uncertainty, which are fundamental to the development of mining projects, mainly due to the great financial risk inherent to decision making at this stage. Thus, it is necessary to understand and identify these sources, so as to measure and control risks, such as geological, economic and socio-political uncertainties [1-4].

The management of cash flows and risk is a critical factor in the success of a mining venture, as well as an integral part of a strategy in developing new and existing operating mines. The choice for reduced production rates extends cash flow, postpones revenue and diminishes potential profits that are obtained only after several years. Conversely, the choice for high production rates substantially increases capital costs, despite tending to maximize the financial return, and also demands a longer timespan for the investment to be paid for [1,5].

Once selected, the mining method and the particularities of the operation should ensure adequate labor conditions, encourage the reduction of impacts to the environment, allow the stability of the mine and be flexible to the geological conditions and the available infrastructure, thus allowing for the achievement of maximum productivity and the reduction of unit and global production costs. The economic feasibility study should take these variants into account, and produce outcomes for several scenarios, in which different cut-off grades, mining and processing equipment, production rates, ore prices, inputs, diverse costs, among other factors are assessed [6,7].

Once restrictions are presumed, the deterministic study by Discounted Cash Flow (DCF) provides an economic evaluation regarding a certain expected Minimum Acceptable Rate of Return (MARR), along with cash flows, Net Present Value (NPV), Internal Rate of Return (IRR), among other rates. However, as the deterministic economic analysis assumes the imposed restrictions and constants to be precisely known over time, even though they shall be subject to several variations whose totality is impossible to predict, there is also a necessity to measure the risk inherent to the suppositions through techniques such as the stochastic risk analysis and the sensitivity analysis $[7,8]$.

Juvenal [9] and Mariz et al. [10] carried out an economic evaluation analysis at Mega Mineração (Mineração Megaípe), a project implemented from the beginning of
2017 until November, 2018 in Jaboatão dos Guararapes, a city in the Metropolitan Area of Recife, Pernambuco, Brazil. This company's economic activity is the extraction and associated processing of granite to produce aggregate for the civil construction industry. They obtained information on technical and economic issues from the group who owns the project, such as mineral reserves, capital costs, the expected production rate, the implemented equipment and its operational particularities, contractual issues, market study, selling portfolio and freight conjuncture, staff budget, among other types of information. The suppliers shared information on the price of machinery acquisition, its maintenance routine and the costs of spare parts.

Thereafter, taxes policy and missing information were obtained in similar projects $[9,10]$.

According to its production scale, it was possible to estimate the annual revenue of the enterprise by means of the average unit value of the mining products multiplied by their annual production. The costs of the project can be segmented into CAPEX (Capital Expenditures), OPEX (Operational Expenditures) and general and administrative costs (divided into overhead and variable), who were calculated considering the production expected. Taxes, contributions and compensation were computed, although some traditional tax incentives such as depreciation, amortization or exhaustion were not applied due to the fiscal modality assumed by the company (presumed profit). They considered three times the annual SELIC (Special System of Settlement and Custody) of August 2018 (6.5\%) as MARR, totalizing 19.5\%. Hence, they submitted the cash flow to MARR according to the length of the project and obtained the NPV of R $\$ 24 \mathrm{MM}$, which allies to an IRR of $169.22 \%$ (among other promising rates), and indicates the probable profitability of the project assuming the accuracy and immutability of the restrictions over time $[9,10]$.

Hereafter, they proceeded to perform the risk analysis of the project, using the Risk Simulator software (2017 version); the program relies on the Monte Carlo probabilistic method to generate stochastic results for the enterprise output (NPV) from the assumption of variables as domains and probability functions, and it uses values of maximum, minimum and most likely within the criteria of optimistic, pessimistic and realistic scenarios. Nine variables were chosen as critical and were simultaneously simulated in 100,000 scenarios, producing a histogram and the cumulative probability distribution of the results for the NPV. Then, a sensitivity analysis was performed, which indicated, through a percentage graph of explained variation, that only two of the nine variables selected were relevant to the result, and other 100,000 scenarios were simulated considering only such variables. This probabilistic analysis showed that there was a $99.77 \%$ probability rate for the NPV to be positive, and $49.98 \%$ for it to be greater than or equal to the deterministic NPV (Figure 1) [9,10].

Although the results indicate a high success probability for the enterprise considering the assumed restrictions, the 


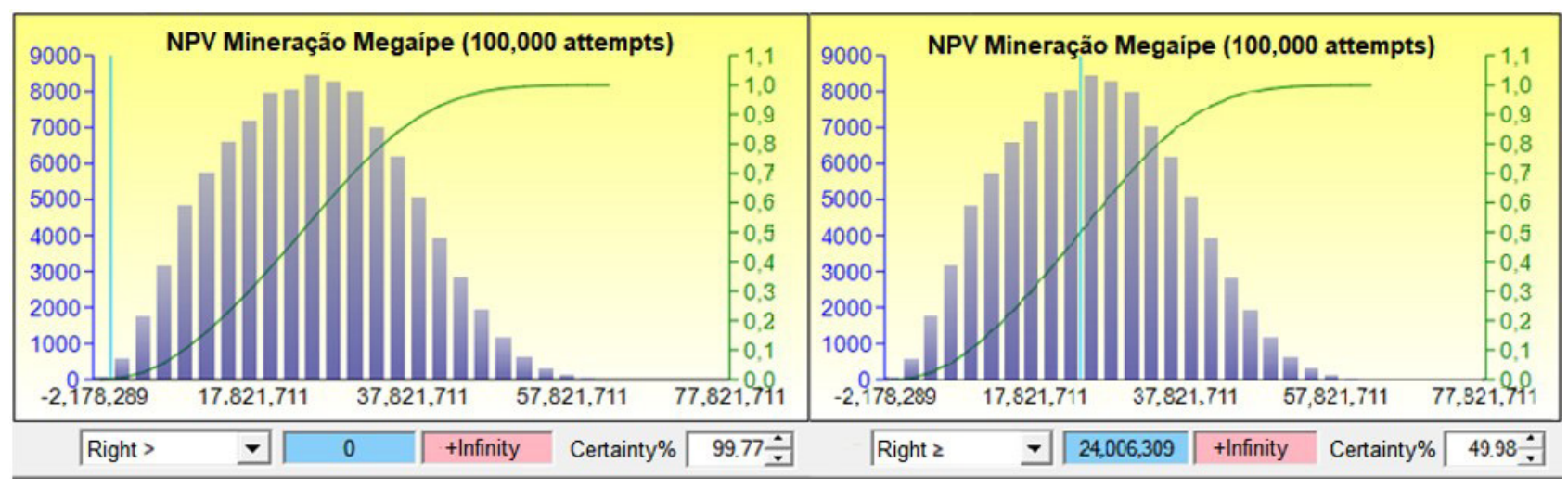

Figure 1. Histogram and distribution of NPV greater than zero and greater or equal to the NPV obtained in the deterministic economic evaluation; primary axis: frequency; secondary axis: cumulative probability $[9,10]$.

risk of breach of contract between the company who owns the mining rights and Mega Megaípe, valid for 15 years, was not considered in the former analyses, and this possibility would render such concretization unviable, due to the reduction of operating time. As the precise number was not supplied, the fine provided for in contract for the party who promotes the rupture was considered equivalent to $\mathrm{R} \$ 2 \mathrm{MM}$, which this study proposes to take account in a new risk analysis, verifying the probabilistic NPV in each possible year when there might be a misunderstanding between parties.

SELIC is the basic interest rate of the Brazilian economy, administered by the Central Bank of Brazil. Basically, it influences all other interest rates in Brazil, such as those charged on loans, financing and even return on financial investments.

As shown in Figure 2, the behavior of the annual SELIC is volatile, although present a pattern of decreasing in the last twenty years. Therefore, this study also proposes to include this rate among the nine variables formerly selected to be analyzed as a statistical distribution, assuring then that the critical influence of the MARR will be considered within the holistic evaluation. The lower the MARR level may be, the smaller may be the influence of economic inflation from one year to another in the NPV, thus having a smaller impact in longer projects than other higher MARR scenarios.

Although the prices of goods and equipment acquisition had slightly changed from 2018 to 2020 , the authors opted to maintain them as in the first publications, as if the elaboration of this analysis took place before the operation started. However, they opted for some changes in the assumption of the working capital and machinery acquisition, attempting to have more verisimilitude. The working capital, formerly arbitrarily considered KR $\$ 500$, was calculated regarding the necessity to cover all variable and overhead costs for two months in a deterministic scenario, where all variables assume the most probable value. On the other hand, the mobilization of processing and mobile machinery was considered before as $30 \%$ of the price of new machines, as most of them had been operating in other quarries from

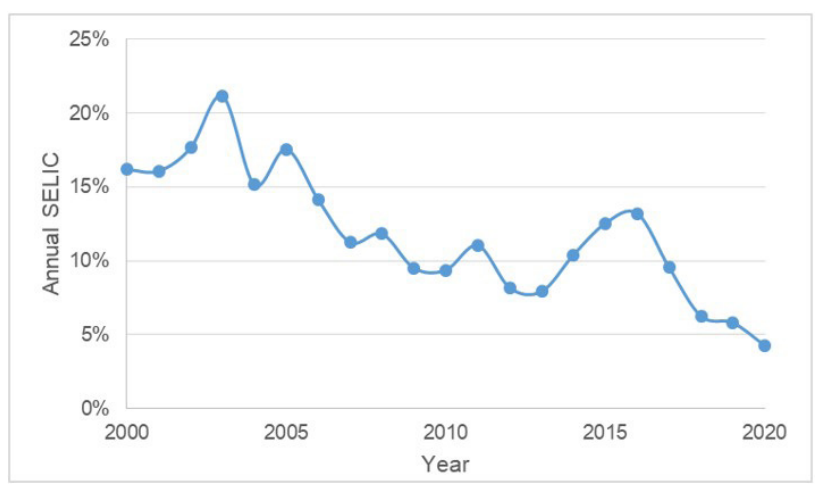

Figure 2. Progression of SELIC indicator from 2000 to 2020.

the Mega Mineração group before its transfer. Instead, this study considered the acquisition of new machinery on the first year, since previous assumption tend to overestimate the NPV and the IRR, since the first years have critical influence on these indicators.

Real Option Valuation (ROV) is another method which became popular to account price uncertainty in mine valuation. Unlike the conventional DCF method, the ROV approach allows one to exercise different options according to market behavior of metal price. For instance, the managers can consider the options of continue, defer, expand or shutdown the operation of a mine depending on the scenario conditions. This study, however, only considered Stochastic Discounted Cash Flow approach [11].

\section{Methodology}

Price composition, capital and operational expenditures (CAPEX and OPEX), taxes, contributions and compensation are exposed in Tables 1 to 5 , and such information was obtained from Juvenal [9] and Mariz et al. [10]. In Table 1, the average production rate, estimated around $25,000 \mathrm{~m}^{3} /$ month, was subdivided in 55\% to clients of the Northern Area of Recife through the DDP (Delivered Duty Paid) modality, 
$25 \%$ would be collected by the customers in the quarry through EXW (Ex Works) modality, and the remaining 20\% would be delivered to clients in the Southern area through the DDP modality.

Thus, the average product value was obtained through the weighted average of these three types of sales, which present differences due to the incorporation (or lack thereof) of freight, as well as the different distances of each area from the enterprise.

Table 2 presents the CAPEX, where infrastructure costs involve earthworks, construction of offices and mechanical garages, installation of crushing equipment and electrical network, among other improvements - although part of the infrastructure had been previously installed by the company who owns the mining rights. The machinery inventory is composed of one driller, one air compressor, two excavators, two loaders, four trucks and the processing equipment (crushers, screeners and conveyors). As aforementioned, the chosen working capital aims for the coverage of variable and overhead costs for two months. Studies on the project involved the renewal of licenses and reporting to government agencies about the lease of the area on behalf of Mega Mineração, a mining engineering consultant, the project of electrical installations, among other costs.

Table 3 supplies variable general costs, leasing and unit operation costs. The minimum monthly lease price of KR \$ 35 must be paid to the legal holder of the land, as well as the mining rights; however, if the value of $4 \%$ of the marketed amount exceeds such value, the lease becomes the percentage of the sale price quoted above. General costs involve administration, mechanical garage and support vehicles. The costs of unit operations involve frequent replenishment of inputs and wear materials, maintenance and replacement of equipment.

Table 4 presents taxes, contributions and compensation costs. The Tax on Circulation of Goods and Transportation and Communication Services (ICMS) in the Pernambuco State affects $18 \%$ of the gross revenue of the enterprise, although the Development Program of Pernambuco (PRODEPE) incentive offers the discount of $75 \%$ of this tax rate for the activity and location of the company. The Contribution for Social Security Financing (COFINS) and Social Integration Program/Public Servants' Patrimony Training Program (PIS/PASEP) accounted for $3 \%$ and $0.65 \%$ of net billing, respectively. Considering that the company is included in the presumed profit regime, the rates of Corporate Income Tax (IRPJ) and Social Contribution on Net Income (CSLL) represent $15 \%$ and $9 \%$ of this, respectively, in addition to the presumption of $8 \%$ and $12 \%$, respectively, which are charged on tax rates. Lastly, the Financial Compensation for the Exploration of Mineral Resources (CFEM) on aggregate mining equals $1 \%$ of net billing.

Table 5 provides the summary of operational costs, in which the "General Annual" column refers to years in which there is no sale and acquisition of new equipment. On the other hand, in years where the exchange of machinery is
Table 1. Price composition

\begin{tabular}{ccc}
\hline Sales Modalities & Unit Price $\left(\mathbf{R} \mathbf{/} / \mathbf{M}^{3}\right)$ & $\begin{array}{c}\text { Percentage Of } \\
\text { Sales (\%) }\end{array}$ \\
\hline DDP North Zone & 75.00 & 55.00 \\
DDP South Zone & 60.00 & 20.00 \\
EXW & 55.00 & 25.00 \\
Average Unit Price & $\mathbf{6 7 . 0 0}$ & \\
\hline
\end{tabular}

Table 2. Total implantation costs (CAPEX)

\begin{tabular}{cc}
\hline Initial Investments & Costs (R\$) \\
\hline Infrastructure & $1.372 \mathrm{MR} \$$ \\
Equipment & $8.385 \mathrm{MR} \$$ \\
Working Capital & $1.585 \mathrm{MR} \$$ \\
Studies and Projects & $80 \mathrm{KR} \$$ \\
Total & $\mathbf{1 1 . 4 2 2} \mathrm{MR} \$$ \\
\hline
\end{tabular}

Table 3. Variable general costs, lease and unit operation costs

\begin{tabular}{ccc}
\hline Item & Monthly (R\$) & Annual (R\$) \\
\hline Lease & $55 \mathrm{M}$ & $660 \mathrm{KR} \$$ \\
General & $30 \mathrm{M}$ & $364 \mathrm{KR} \$$ \\
Blasting & $40 \mathrm{M}$ & $482 \mathrm{KR} \$$ \\
Drilling & $41 \mathrm{M}$ & $486 \mathrm{KR} \$$ \\
Loading & $132 \mathrm{M}$ & $1.582 \mathrm{MR} \$$ \\
Haulage & $31 \mathrm{M}$ & $372 \mathrm{KR} \$$ \\
Processing & $120 \mathrm{M}$ & $1.440 \mathrm{MR} \$$ \\
Total & $\mathbf{4 4 9 M}$ & $\mathbf{5 . 3 8 6} \mathbf{M R} \$$ \\
\hline
\end{tabular}

Table 4. Taxes, contributions and compensation

\begin{tabular}{ccc}
\hline Item & Monthly (R\$) & Annual (R\$) \\
\hline IRPJ & $20 \mathrm{M}$ & $242 \mathrm{KR} \$$ \\
ICMS & $76 \mathrm{M}$ & $907 \mathrm{KR} \$$ \\
COFINS & $50 \mathrm{M}$ & $604 \mathrm{KR} \$$ \\
PIS/PASEP & $11 \mathrm{M}$ & $131 \mathrm{KR} \$$ \\
CSLL & $18 \mathrm{M}$ & $218 \mathrm{KR} \$$ \\
CFEM & $14 \mathrm{M}$ & $165 \mathrm{KR} \$$ \\
Total & $\mathbf{1 8 9 M}$ & $\mathbf{2 . 2 6 7} \mathbf{M R \$}$ \\
\hline
\end{tabular}

foreseen due to depreciation, such as 2022, 2025 and 2027, there is the generation of extra revenue (residual value of $30 \%$ of the price of a new equipment) and costs (purchase of machinery).

The reserves declared are 3,183,124.70 $\mathrm{m}^{3}$ in situ, or $4,774,687.05 \mathrm{~m}^{3}$ blistered. Staff salaries and charges (insalubrity, dangerousness, nocturnal additional payments, National Social Security Institute - INSS and Service Guarantee Fund - FGTS percentages, vacation payments and the thirteenth salary), in addition to meals and Equipment for Individual Safety (EIS) were estimated in MR\$ 1.588 per annum. Administrative costs were considered, such as internet providers, telephone costs, security, administrative system, accounting and pro-labore values for the partners. Although, costs of mine closure and a possible environmental rehabilitation were not considered, due to the fact that it is not possible to exhaust whole ore in a first lease of 15 years, 
once it is probable that the holder of the mining right might lease the enterprise again, to the same group or another one.

In this context, this study aims for the possibility of breach of contract by the owner of the mineral rights in each one of the 15 years, and assesses its possible consequences to Mega Mineração, analyzing the NPV and IRR in each scenario. Firstly, the information provided in the former section was organized in such a way that revenue, costs and taxes resulting from the determined production rate could provide annual cash flows.

When submitted to a MARR, the sum of the cash flows in the project must provide the NPV and IRR of the scenario attached to the imposed restrictions. Regarding the dismantle of the enterprise in a given year, it is determined to perform the sale of the machinery in the subsequent year for a price that is proportional to its use, but never for less than the $30 \%$ considered as residual value; the cost of KR\$ 300 for demobilization of equipment and facilities is also considered, in addition to legal issues due to staff dismissal; the working capital returns, and the penalty of MR\$ 2 agreed for in the contract is also considered.

Table 6 presents the variables defined as critical to the project, and the column "Probable Value" provides the values assumed in the economic deterministic analysis, which supplies an NPV and IRR for each scenario observed in the study, which already indicates the consequences of rupture to the enterprise. Nevertheless, as the deterministic analysis assumes that the values chosen for each variable are accurate and constant over the timespan of the venture, a probabilistic analysis is indicated to avoid biases and to supply investors with a consistent tool for risk prediction. Table 6 also provides the statistical distributions selected to represent the variables submitted to changes over the years, transmuting numbers into statistical domains. Minimum and Maximum values were defined to each variable which, in addition to the most probable value, defines the limits of the statistical distribution selected, i.e. PERT (Program Evaluation and Review Technique) or triangular distribution, depending on the case.

Besides "Annual SELIC (\%) (MARR)" addition, the difference from former researches is given to the "Maximum Value" column of the "Monthly production rate $\left(\mathrm{m}^{3}\right)$ " line, which became a variable, as shown in Figure 3. Considering the capacity of mobile machinery and the processing plant, Juvenal [9] and Mariz et al. [10] considered 55,000 $\mathrm{m}^{3}$ as maximum monthly production rate, but longer lifetimes couldn't afford this constant production, due to the exhaustion of the reserves. As this study intend to perform a yearly analysis, the maximum capacity to avoid the mineral reserves exhaustion was considered in each scenario assessed.

The probabilistic approach carried out in the Risk Simulator software (2017 version) initially consists of running 100,000 Monte Carlo simulations in the ideal scenario, in which the contract has not been breached ( 15 th year). Thus, the ten variables simultaneously assume stochastic values under the constrains of each statistical domain, and the

Table 5. Total operational costs (OPEX)

\begin{tabular}{ccccc}
\hline Operational Costs & General Annual (MR\$) & 2022 (MR\$) & 2025 (MR\$) & 2027 (MR\$) \\
\hline Variable & 7.758 & 8.598 & 10.243 & 8.867 \\
Overhead & 1.756 & 1.756 & 1.756 & 1.756 \\
Total & $\mathbf{9 . 5 1 4}$ & $\mathbf{1 0 . 3 5 4}$ & $\mathbf{1 1 . 9 9 9}$ & $\mathbf{1 0 . 6 2 3}$ \\
\hline
\end{tabular}

Table 6. Statistical distributions and probable, minimum and maximum values of each variable submitted to the sensitivity and risk analysis

\begin{tabular}{|c|c|c|c|c|}
\hline Variable & Statistical Distribution & Minimum Value & Probable Value & Maximum Value \\
\hline $\begin{array}{l}1 \text { Monthly production rate } \\
\left(\mathrm{m}^{3}\right)\end{array}$ & PERT & $15,000.00$ & $25,000.00$ & Variable \\
\hline $\begin{array}{l}2 \text { Annual SELIC (\%) } \\
\text { (MARR) }\end{array}$ & PERT & 3.00 & 6.50 & 20.00 \\
\hline 3 Cost of fuel $(\mathrm{R} \$ / \mathrm{L})$ & Triangular & 3.20 & 3.69 & 5.20 \\
\hline $\begin{array}{l}4 \text { Electric energy }(\mathrm{R} \$ / \\
\mathrm{kWh})\end{array}$ & Triangular & 0.85 & 0.92 & 1.20 \\
\hline $\begin{array}{l}5 \text { Emulsion explosive } \\
(\mathrm{R} \$ / \mathrm{Kg})\end{array}$ & Triangular & 2.90 & 3.50 & 4.50 \\
\hline $\begin{array}{l}6 \text { Sale price Northern } \\
\text { Zone }\left(\mathrm{R} \$ / \mathrm{m}^{3}\right)\end{array}$ & Triangular & 60.00 & 75.00 & 90.00 \\
\hline $\begin{array}{l}7 \text { Sale price Southern } \\
\text { Zone }\left(\mathrm{R} \$ / \mathrm{m}^{3}\right)\end{array}$ & Triangular & 48.00 & 60.00 & 72.00 \\
\hline 8 Sale price EXW $\left(\mathrm{R} \$ / \mathrm{m}^{3}\right)$ & Triangular & 44.00 & 55.00 & 66.00 \\
\hline $\begin{array}{l}9 \text { Distribution DDP } \\
\text { Northern Zone (\%) }\end{array}$ & Triangular & 51.00 & 56.00 & 61.00 \\
\hline 10 Distribution EXW (\%) & Triangular & 20.00 & 25.00 & 30.00 \\
\hline
\end{tabular}


assessed outputs are NPV and IRR, even though the first one is the most relevant rate for the DCF analysis. These NPV and IRR values were then grouped in two histograms and cumulative probability distributions. Furthermore, a sensitivity analysis was performed, indicating through a percentage graph of explained variation which ones of the ten variables selected are relevant to the outputs, whose decision must guide the next steps of stochastic simulations. Then, another set of 100,000 Monte Carlo simulations were performed in each one of the fifteen scenarios, predicting possibilities of NPV and IRR results in case of breaching the contract from year to year, generating the final histograms and cumulative probability distributions for each scenario.

Thus, this risk analysis evaluate several possibilities under a huge ensemble of values assumed simultaneously by the critical variables, generating a set of histograms and cumulative probability distributions beyond just one NPV and one IRR as in a deterministic economic analysis, which makes this approach a most robust tool to assess the success probabilities of the project.

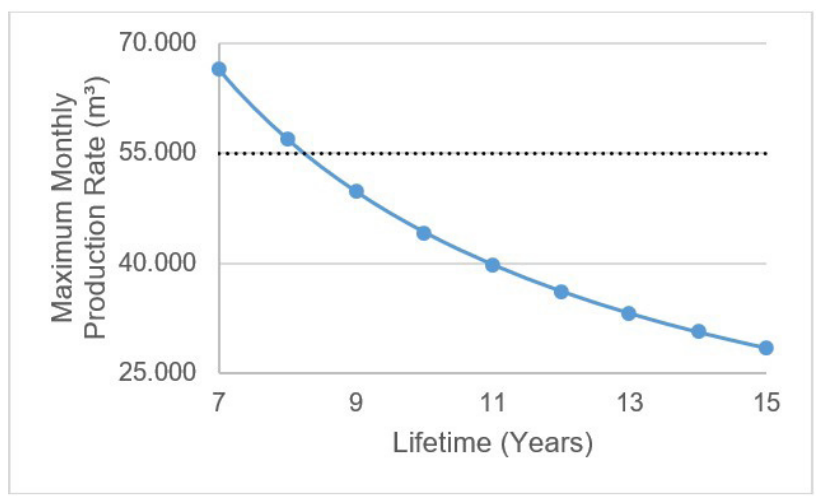

Figure 3. Maximum Monthly Production Rate $\left(\mathrm{m}^{3}\right)$ considering the reserves declared and corresponding Lifetimes of the enterprise.

\section{Results and discussion}

The deterministic economic assessment considering the fulfillment of the contract time, along with these new contexts and modifications, provided an NPV equal to MR \$ 9.570 and an IRR of $35.07 \%$, which represents a high profitable project, as the NPV is bigger than zero and the IRR is bigger than all MARRs simulated. Regarding the probabilistic economic assessment, the sensitivity analysis proved that, among the ten variables provided in Table 6, only the Monthly production rate $\left(\mathrm{m}^{3}\right)$, the Annual SELIC $(\%)$ and the Sale price for the Northern Area $\left(\mathrm{R} \$ / \mathrm{m}^{3}\right)$ were relevant to the risk analysis, as supplied in Figure 4, where they had an influence of $87.02 \%$ and $88.31 \%$ in NPV and IRR results, respectively.

Table 7 shows the probability of the NPV to be greater than zero and be greater than or equal to the deterministic NPV, and also shows the probability of the IRR to be greater than the biggest MARR considered (20\%), as well as the probability of it being greater than or equal to the deterministic MARR. It is noticeable that shorter scenarios present less probability of achievement of the expected results in deterministic DCF analysis, presenting even lower perspectives of achieving any success in case of breach of contract during the first years of enterprise.

Figure 5, in turn, provides a chart from the information provided in Table 7; although the behavior of the curves shows good correlation, the curve "IRR $\geq 35.07 \%$ " exhibit a divergent conduct in longer scenarios. This perception motivated the composition of Table 8 , which displays the Pearson correlation coefficient for NPV and IRR, using their rates, along with the three variables elected as relevant in the longer scenario, in which there was no breach of contract. The numbers display higher correlation of IRR than NPV to the production rate, and due to a necessity of reducing the production in longer scenarios to prevent faster exhaustion of reserves, this reduction affected the IRR more than it affected the NPV.

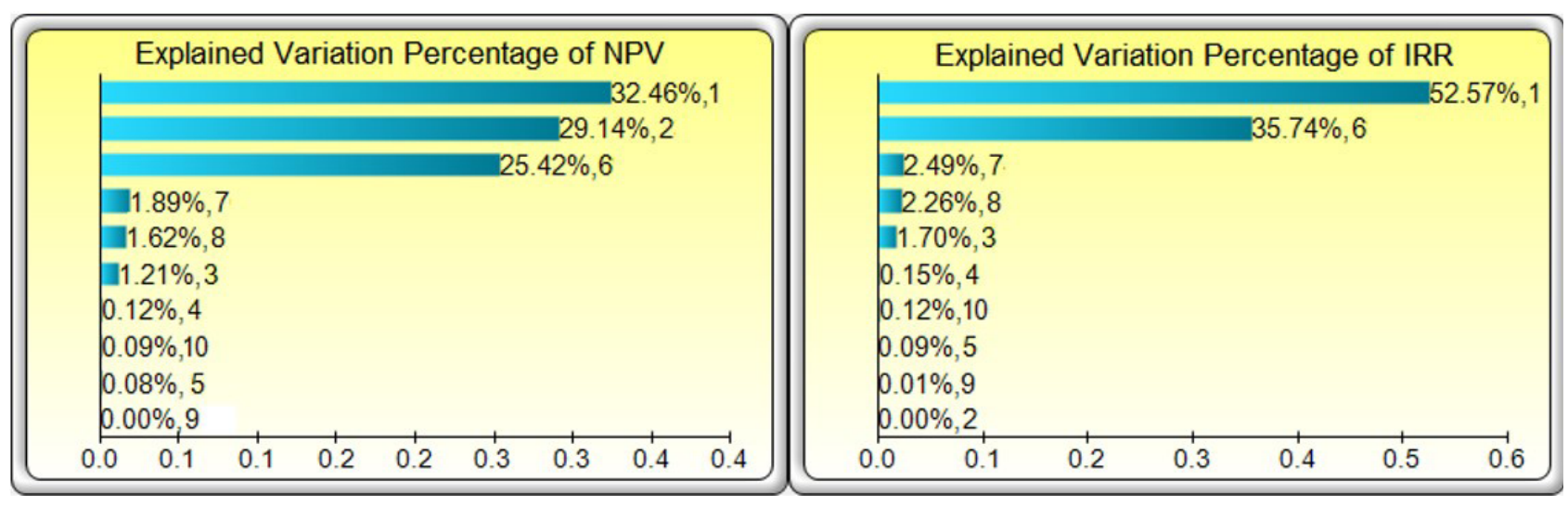

Figure 4. Explained Variation Percentage of NPV and IRR, related to Table 6 variables. 
Table 7. Probability of the NPV to be greater than zero and greater than or equal to the deterministic NPV; probability of the IRR to be greater than the highest MARR and greater than or equal to the deterministic MARR

\begin{tabular}{ccccc}
\hline Probability & NPV $>$ R\$ 0.00 & NPV $\geq$ MR 9.750 & IRR $>\mathbf{2 0 . 0 0 \%}$ & IRR $\geq \mathbf{3 5 . 0 7 \%}$ \\
\hline $1^{\text {st }}$ Year & $0.00 \%$ & $0.00 \%$ & $0.00 \%$ & $0.00 \%$ \\
$2^{\text {nd }}$ Year & $34.42 \%$ & $0.52 \%$ & $16.22 \%$ & $5.21 \%$ \\
$3^{\text {rd }}$ Year & $66.89 \%$ & $18.83 \%$ & $44.72 \%$ & $23.57 \%$ \\
$4^{\text {th }}$ Year & $79.91 \%$ & $40.50 \%$ & $59.63 \%$ & $36.04 \%$ \\
$5^{\text {th }}$ Year & $86.50 \%$ & $55.38 \%$ & $68.05 \%$ & $43.96 \%$ \\
$6^{\text {th }}$ Year & $89.77 \%$ & $64.76 \%$ & $72.62 \%$ & $48.23 \%$ \\
$7^{\text {th }}$ Year & $92.21 \%$ & $71.47 \%$ & $76.06 \%$ & $51.61 \%$ \\
$8^{\text {th }}$ Year & $93.79 \%$ & $77.01 \%$ & $79.01 \%$ & $54.46 \%$ \\
$9^{\text {th }}$ Year & $94.66 \%$ & $78.95 \%$ & $79.28 \%$ & $51.91 \%$ \\
$10^{\text {th }}$ Year & $95.68 \%$ & $80.22 \%$ & $81.37 \%$ & $49.37 \%$ \\
$11^{\text {th }}$ Year & $96.51 \%$ & $83.30 \%$ & $80.87 \%$ & $45.82 \%$ \\
$12^{\text {th }}$ Year & $97.17 \%$ & $84.98 \%$ & $81.62 \%$ & $42.38 \%$ \\
$13^{\text {th }}$ Year & $97.88 \%$ & $87.04 \%$ & $82.85 \%$ & $38.38 \%$ \\
$14^{\text {th }}$ Year & $98.51 \%$ & $88.98 \%$ & $84.17 \%$ & $33.70 \%$ \\
$15^{\text {th }}$ Year & $100.00 \%$ & $84.44 \%$ & $77.28 \%$ & $18.13 \%$ \\
\hline
\end{tabular}

Table 8. Pearson correlation coefficient for NPV and for IRR in a longer scenario ( $15^{\text {th }}$ year)

\begin{tabular}{cccccc}
\hline & NPV & IRR & Monthly production rate & MARR & Sale price Northern Zone \\
\hline NPV & 1.00 & 0.82 & 0.61 & -0.55 & 0.53 \\
IRR & 0.82 & 1.00 & 0.78 & 0.00 & 0.62 \\
\hline
\end{tabular}

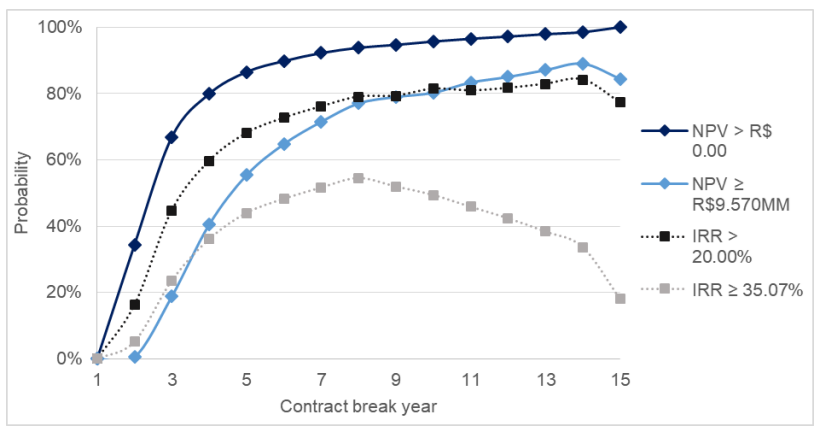

Figure 5. Probability of NPV to be greater than zero and greater than or equal to the deterministic NPV; probability of the IRR to be greater than the highest MARR, and greater than or equal to the deterministic MARR.

\section{Conclusions}

The Economic Feasibility Study under a probabilistic approach, once again, proved to be a powerful tool for risk assessment, as it considers the critical variables for the enterprise as statistical distributions, instead of a fixed number, and as it provides the probability of some parameters to happen instead of just a rate. This study aimed to perform the assessment of breach of contract risks, and its consequences in each one of the years foreseen for the enterprise, employing (for this purpose) some modifications on considerations made by former researches, such as the assumption of MARR as statistical distribution, working capital and machinery acquisition.
The deterministic analysis based in the fulfillment of the contract time supplied MR\$ 9.750 as NPV and 35.07\% as IRR, which initially indicates a high profitable project, due to the positive NPV rate and to the IRR higher than all simulated MARRs. The risk analysis, however, proved that if the contract was to be breached in the fourth year of operation, the probability of achieving that NPV would be at $40.50 \%$, and there would be a $20.09 \%$ probability of the NPV to be negative. If the rupture happens in the third year, the probability of achieving the deterministic NPV is $18.83 \%$, though $33.11 \%$ is the probability of the NPV to be negative. In the second year, the results were even more critical, and if the rupture were to occur in the first year, there is no probability of achieving any profit, making the enterprise a complete disaster. The IRR, in turn, has a similar behavior to the NPV, in which its probability of achievement of higher values lowers as the project becomes shorter. However, the probability of the IRR reaching higher values in stochastic evaluations considering longer scenarios with diminished production rates is reduced, due to the influence that production rate inflicts on the IRR being bigger than on NPV, hence only the first variable presenting a decreasing behavior.

After reiterating the relevance of the topic, in which the risk of breach of contract showed itself a critical factor of success for an enterprise, mainly if it occurs in the early years of the project, it is important to discuss the particularities of the case.

The necessity of reducing the maximum constant production rate in longer scenarios reduced both the possibilities 
of the NPV to reach higher levels when compared to greater production rates in shorter scenarios. If the production rates were the same in all the years when the contract was to be breached, probably the longer enterprises would have their results highlighted. Thereby, as in several other mines, it is possible to notice the importance of the scale factor, when aggressive production rates, as long as reserves justify the higher capital and operating costs, tend to supply higher NPV and TIR. The assumption of MARR as a variable enables a broader analysis, considering then optimistic and pessimistic scenarios instead of only a conservative scenario for safety issues, thus including higher NPVs and IRRs among the possibilities. Finally, projects with narrow profit margins would suffer a bigger influence from such risk than this studied quarry, so it is essential to carry out an investigation similar to this one in order to quantify correctly the penalties provided for in the contract, in cases when it may be violated, otherwise the damage could be enormous.

\section{References}

1 Mariz JLV, Peroni RL. Análise da aderência à realidade brasileira dos métodos de previsão da taxa de produção em fases prematuras de projeto. In: Instituto Brasileiro de Mineração. Proceedings of $9^{\circ}$ Congresso Brasileiro de Minas a Céu Aberto e Minas Subterrâneas - Gestão de risco na Mineração: da exploração mineral ao produto final; 2018 August 1-3; Belo Horizonte, Brazil. Rio de Janeiro: IBRAM; 2018.

2 Dimitrakopoulos RG, Farrelly CT, Godoy M. Moving forward from traditional optimization: grade uncertainty and risk effects in open-pit design. Mining Technology. 2002;111(1):82-88. http://dx.doi.org/10.1179/mnt.2002.111.1.82.

3 Peroni RL. Análise da sensibilidade do sequenciamento de lavra em função da incerteza do modelo geológico [thesis]. Porto Alegre: Universidade Federal do Rio Grande do Sul; 2002.

4 Cherchenevski PK, Costa JFCL, Rubio RH. Grade uncertainty embedded in long term scheduling: stochastic mine planning. REM - International Engineering Journal. 2019;72(2):275-284. http://dx.doi.org/10.1590/037044672018720119.

5 Dimitrakopoulos RG, Martinez L, Ramazan S. A maximum upside / minimum downside approach to the traditional optimization of open pit mine design. Journal of Mining Science. 2007;43(1):73-82. http://dx.doi.org/10.1007/ s10913-007-0009-3.

6 Rocha SS, Souza JC, Vasconcelos SLD, Mariz JLV. Análise comparativa de métodos de lavra na mineração de gipsita em Pernambuco. In: Associação Brasileira de Metalurgia, Materiais e Mineração. Proceedings of $19^{\circ}$ Simpósio de Mineração; 2018 October 6-8; São Paulo, Brasil. São Paulo: Blucher Proceedings; 2018. p. $456-467$.

7 Darling P. SME - Mining Engineering Handbook. 3th ed. Littleton: SME - Society for Mining, Metallurgy, and Exploration, Inc; 2013.

8 Gentry DW, O’Neil TJ. Investment Analysis. In: Hartman HL. SME - Mining Engineering Handbook. 2nd ed. Littleton: SME - Society for Mining, Metallurgy, and Exploration, Inc; 1996. p. 452-469.

9 Juvenal RS. Estudo de viabilidade econômica preliminar de um projeto de mineração de agregados em fase de implantação na Região Metropolitana do Recife-PE. Recife: Universidade Federal de Pernambuco; 2018.

10 Mariz JLV, Juvenal RS, Rocha SS, Assis AAA, Souza JC. Preliminary study of economic feasibility of a project of aggregates mining through probabilistic analysis. In: Associação Brasileira de Metalurgia, Materiais e Mineração. Proceedings of $20^{\circ}$ Simpósio de Mineração; 2019 October 1-3; São Paulo, Brasil. São Paulo: Blucher Proceedings; 2019. p. 215-226.

11 Hazra T, Samanta B, Dey K. Real option valuation of an Indian iron ore deposit through system dynamics model. Resources Policy. 2019;60:288-299. http://dx.doi.org/10.1016/j.resourpol.2019.01.002.

Received: 10 Mar. 2020

Accepted: 23 Nov. 2020 